\title{
USUL FIKIH DAN UPAYA REORIENTASI FIKIH INDONESIA
}

\author{
Munawir Haris \\ Jurusan Syariah Sekolah Tinggi Agama Islam (STAIN) Sorong \\ Klamono KM.17, J. Sorong-Aimas, Klablim, Sorong Timur, Kota Sorong, Papua Barat 98414 \\ Email: Irfani.Fanani@gmail.com
}

\begin{abstract}
In classical fiqh which is based on the classic Proposal of Jurisprudence, it is often considered outdated and has no effectiveness in dealing with new problems. This paper tries to provide a description of substantive clarification between sharia and fiqh, which is the area of proposal (sharia) and which branch area (fiqh) Then the discussion continued with its urgency through a hermeneutic approach in carrying out Indonesian local jurisprudence. The Qur'anic texts are fixed, God's laws also do not change and do not change. He never subsided from time to time and from society to other communities. Therefore, changes and changes are only about efforts to adjust and apply the laws of God to the conditions of society and the situation of the times. In other words, fiqh is essentially the result of efforts to harmonize the Shari'a with the conditions of the society and its era. Especially in the Indonesian context, fiqh must also be adapted to the socio-cultural conditions of the Indonesian people known as Indonesian Islamic Jurisprudence or Nusantara Islamic Jurisprudence.
\end{abstract}

Keywords: Methodology in Islamic Jurisprudence, Islamic Jurisprudence, Indonesia

\begin{abstract}
Abstrak: Dalam fikih klasik yang didasarkan pada Usul Fikih klasik, sering dianggap ketinggalan zaman dan tidak memiliki efektivitas dalam menangani masalah-masalah baru, Tulisan ini mencoba memberikan uraian klarifikasi secara substantif antara syariah dan fikih, mana wilayah usul (syariah) dan mana wilayah cabang (fikih). Kemudian pembahasan dilanjutkan dengan urgensinya melalui pendekatan hermeneutik dalam menjalankan fikih lokal Indonesia. Teks-teks Alquran adalah tetap, hukum-hukum Allah juga tidak berubah dan tidak berganti. Ia tidak pernah surut dari masa ke masa dan dari masyarakat ke masyarakat lainnya. Oleh sebab itu, perubahan dan pergantian hanyalah mengenai upaya penyesuaian dan penerapan hukum-hukum Allah tersebut dengan kondisi masyarakat dan situasi zaman. Dengan kata lain, fikih pada hakekatnya merupakan hasil usaha penyelarasan syariat dengan kondisi mayarakat dan zamannya. Khusus konteks Indonesia, fikih juga harus disesuaikan dengan kondisi sosio-kultural bangsa Indonesia yang dikenal dengan istilah Fikih Indonesia atau Fikih Nusantara.
\end{abstract}

Kata kunci: Usul Fikih, Fikih, Indonesia

\section{Pendahuluan}

Pada zaman Nabi hidup, bibit konflik antara sekelompok ahl al-naqli dan ahl al-aqly sudah ada di kalangan para sahabat dengan sepengetahuan nabi. Setelah nabi wafat, dilakukan upaya teoritisasi hukum abad ke-2 Hijriah. Saat itu, konflik sangat nyata telihat. Hal ini tampak dari adanya dua orinteasi utama dalam pemikiran hukum Islam, yaitu ahl-hadits (kelompok yang lebih mengutamakan hadis) dan ahl al-ra'y (kelompok yang lebih mengutamakan penalaran rasional). Usul Fikih terlibat dalam menghadapi problem klasik ini, melerai konflik antara wahyu dan akal.
Jika disepakati Imam Syafi'i adalah Bapak Usul Fikih dengan kitab Risalah-nya, maka munculnya ilmu ini dan pengarangnya boleh jadi sebagai latar belakang munculnya Usul Fikih itu sendiri. ${ }^{1}$ Maka dari segi ini, Usul Fikih lahir dengan misi regulasi. Hadirnya imam Syaf'i menandai babak baru dalam kancah pemikiran hukum Islam, orang mestilah menguasai teori untuk menjadi seorang Faqih. Sejak itu, prasyarat

${ }^{1}$ Hasil penelitian tentang pernikiran hukum sebelum Imam Syafi'i bisa dibaca pada Ahmad Hasan, Pintu Ijtihad Sebelum Tertutup, Terj. Agah Garnadi (Bandung: Pustaka, 1994), h. 117. Contoh kasus-kasus keputusan hukum yang dikecam sebagai tidak konsisten oleh Syafi'i banyak ditampilkan. 
penguasaan teori hukum untuk mendapatkan hukum dari dalilnya menjadi aturan main yang baku. ${ }^{2}$ Dalam hal ini, Usul Fikih menguraikan dalil-dalil, metode deduksi hukum-hukum fikih dari sumbernya. Fikih adalah produk akhir dari Usul Fikih, namun keduanya merupakan bidang yang berbeda dan berdiri sendiri. ${ }^{3}$

Secara umum, tujuan diciptakan syariat Islam adalah terwujudnya suatu kemaslahatan di tengah-tengah masyarakat dengan baik, tidak mengenal batasan ruang dan waktu. ${ }^{4}$ Dalam konteks Indonesia, fikih yang dipahami oleh mayoritas umat adalah syariah. Padahal, keduanya sangat berbeda, ibarat cabang dan asal. Dari sini, maka dianggap wajar adanya gagasan fikih mazhab nasional ${ }^{5}$ atau fikih Indonesia ${ }^{6}$ walaupun pada mulanya terjadi reaksi dari pihak-pihak yang menentangnya. ${ }^{7}$ Untuk itu, diperlukan kajian serius terhadap persoalan syariah untuk melahirkan fikih nuansa baru dewasa ini, sehingga tidak tercabut dari akar kultur budaya dimana konsumen fikih (masyarakat) berada. Perlunya langkah berani dari para akademisi untuk melakukan terobosan baru, sehingga fikih dan syariah selalu dinamis sesuai dengan konteks

${ }^{2}$ Kecuali Mazhab Hanafi berbeda dari tradisi yang diterapkan oleh Syafi'i dan para penggemarnya. Untuk lebih juah tentang hal itu lihat: Imran Ahsan Khari Nyazee, Theories of Islamic Law: The Methodology of litihad (lslamabad: The Intemational Institute of lslamic Thought, 1994), h. 30.

${ }^{3}$ Dalam kacamata usul fiqh hukum selalu memiliki sumber dan memahami sumber-sumber itu mesti dengan kualifikasi penguasaan terhadap kaidah-kaidah deduksi dan interpretisi. Kalau nash al-Qur'an dan Sunnah tidak dipahami secara tepat, maka tidak ada hukum yang bisa dideduksi darinya, terutama jika nash itu bukan merupakan dalil yang berdiri sendiri.

${ }^{4}$ Imam Sythibi sebagai Bapak Maqashid al-Syari'ah Pertama sekaligus sekilas tentang Maqashid al-Syari'ah versi Syathibi. mencoba menggabungkan teori-teori (nadhariyyat) Ushul Fiqh dengan konsep Maqashid al-Syari'ah, sehingga produk hukum yang dihasilkan lebih hidup dan lebih kontekstual. Musthafa Said al-Khin, al-Kafi al-Wafi fi Ushul al-Figh al-Islamy, Beirut: Muassasah risalah, 2000, h. 8. Lihat juga Abu Ishaq al-Syathibiy, al-Muwafaqat Fi Ushul al-Syariah, Juz II, Tahqiq Abdullah Daraz (Beirut: Dar al-Kutub al-Ilmiyyah, t.th), h. 3-7

5 Hazairin, Tujuh Serangkai tentang Hukum, (Jakart: Tintamas, 1974), h. 115

${ }^{6}$ Hasbi As-Shiddiqiy, Syariat Islam Menjawab Tantangan Zaman, (Jakarta: Bulal Bintang, 1966), h. 43

7 Dalam hal ini diwakili oleh Ali Yafie dan Ibrahim Hosen. Lihat Ali Yafie, "Matarantai Yang Hilang", Pesantren, No. 2 Vol. II 1985, h. 30. Lihat pula Ibrahim Hosen, "Pemerintah sebagai Mazhab”, Pesantren, No. 2 Vol. II 1985, h. 45-46. dan relevansi masyrakat setempat dengan tetap menjunjung tinggi nilai dan spirit Alquran dan hadis sebagai induk dari peradaban Islam.

Tulisan ini mencoba memberikan uraian klarifikasi secara substantif antara syariah dan fikih, mana wilayah usul (syariah) dan mana wilayah cabang (fikih). Kemudian pembahasan dilanjutkan dengan urgensinya melalui pendekatan hermeneutik dalam menjalankan fikih lokal Indonesia. Kemudian dari sana dapat dipahami keberanian tokoh-tokoh Nasional melakukan upaya reorientasi fikih Indonesia/ fikih Nusantara untuk mencari kemaslahatan umat. Tulisan ini diakhiri dengan kesimpulan sebagai sebuah refleksi.

\section{Syariah dan Fikih}

Dalam realitasnya, fikih yang dihasilkan para ulama merupakan hasil pemahaman dan interpretasi para ulama terhadap hukam syariah (aturan-aturan partikular dalam Alquran) dan bukan terhadap syariah (nilai universal, manhaj dan metode Alquran sebagai landasan dalam menetapkan hukum) itu sendiri. Dalam arti bahwa yang menjadi fokus kajian para ulama adalah teks-teks yang berkaitan dengan aturan dan kaidah hukum yang bersifat partikular dalam Alquran dan hadis, dan seringkali mengabaikan manhaj dan metode yang digunakan syariah dalam menetapkan kaidah dan aturan hukum tersebut. Padahal, sebagaimana dikemukakan dalam QS. Al-Jatsiyah (45) ayat 1-8, Alquran secara eksplisit memerintahkan untuk mengikuti syariah sementara al-ahkam al-syari ah harus dipahami sebagai implementasi partikular dari syariah yang ditetapkan maksud, tujuan, dan konteks ketika diturunkannya. ${ }^{8}$

${ }^{8}$ Di samping itu, pemahaman dan interpretasi ulama terhadap Ahkam Asyariah yang berupa fiqh tersebut, baik sadar maupun tidak, dipengaruhi oleh kondisi sosial budaya tempat ulama tersebut hidup. Bahkan sungguhnya hasil pemahaman dan interpretasi ulama tersebut dapat dikatakan sebagai respon terhadap budaya dan kebiasaan masyarakat yang dihadapi. Pengertian ini memunjukkan bahwa fiqh merupakan produk pemikiran ulama (faqih) yang bersifat temporal, lokal, dan kontekstual yang diderivasi dan disimpulkan dari syariah dan al-Ahkamu Asyariah. Lokalitas dan kontekstualitas pada dasarya merupakan sifat dasar dari fiqh, dan ini yang membedakannya dengan syariah yang berasal dari Allah dan Rasul-Nya yang 
Syariat Islam dengan kedua sumber pokoknya Alquran dan sunah dengan demikian tidaklah lahir dalam masyarakat yang tanpa kultural, di samping sebagai konsep Ilahi yang mengajarkan tentang kebenaran, sekaligus menjadi pedoman hidup manusia dalam segala aspeknya. Antara syariah dan fikih bukan saja berbeda dalam arti harfiahnya, tetapi juga berbeda secara terminologis dan substansialnya. ${ }^{9}$ Secara harfiyah, kata syariah berarti jalan menuju tempat mata air, atau tempat yang dilalui air sungai. Penggunaannya dalam Alquran diartikan sebagai jalan lurus yang membawa kemenangan. Sedangkan dalam terminologi ulama ushul fikih, syariah adalah titah (kitab) Allah Swt yang berhubungan dengan perbuatan orang-orang mukallaf (muslim, baligh dan sehat akal), baik berupa tuntutan, ketetapan atau pilihan (sebab, syarat dan penghalang). ${ }^{10}$

Mahmud Syaltut dalam bukunya al-Islam 'Aqidah wa Syariah memberikan definisi syariah dengan peraturan yang diturunkan Allah Swt kepada umat manusia agar dijadikan sebagai pedoman dalam berhubungan dengan Tuhannya, dengan sesamanya, dengan lingkungannya dan dengan kehidupan. ${ }^{11}$ Syariah meliputi semua aspek ajaran Islam yakni: aqidah, ibadah, muamalah dan akhlaq ${ }^{12}$.

Sementara fikih dalam istilah Indonesia disebut dengan "Fikih", "Fikih" atau "Fekih"13 secara etimologis bisa diartikan dengan paham atau pengertian, ${ }^{14}$ mengetahui sesuatu, memahaminya sampai pada hal yang sangat dalam. ${ }^{15}$ Sedangkan dalam pengertian terminologis, fikih adalah hukum-

\footnotetext{
diyakini bersifat universal.

9 Mun'im A. Sirry, Sejarah Figh Islam sebuah Pengantar (Surabaya: Risalah Gusti, 1995/1416), h. 17

${ }^{10}$ Abd. Wahhab Khallaf, 'Ilm Ushul al-Figh (Kuwait: Dar al-Qalam, 1978/1398), h. 100. Lihat pula Badran Abu al-“Ayn Badran, Ushul al-Figh al-Islamiy (Iskandariyah: Muassasah alSaqafat al-Jami'iyyah, t.th.), h. 26

${ }^{11}$ Mahmud Syaltut, al-Islam 'Aqidah wa Syari'ah (Mesir: Dar al-Qalam, 1966), h. 12

${ }_{12}$ Ahmad Rafiq, Hukum Islam di Indonesia (Jakarta: Raja Grafindo Persada, 1995), h. 4

13 Istilah-istilah tersebut dapat dilihat pada Mohammad Daud Ali, Hukum Islam, Pengantar Ilmu Hukum dan Tata Hukum Islam di Indonesia (Jakarta: Raja Grafindo Persada, 1993), h. 43

${ }^{14}$ Lihat antara lain: Q.S. al-Taubah (9): 122; al-Kahfi (18); 57; al-Isra (17): 16; al-An'am (6): 25.

${ }^{15}$ Badran Abu al-"Ayn Badran, Ushul al-Figh al-Islamiy..., h. 23
}

hukum syara' yang bersifat praktis (amaliyah) yang diperoleh berdasarkan dalil-dalil yang rinci (tafshiliy). ${ }^{16}$ Sementara Hasbi As-Shiddiqi memberikan rumusan bahwa fikih adalah koleksi hukum Islam dalam berbagai mazhab, termasuk yang di luar mazhab empat (Syafi'i, Hambali, Hanafi dan Maliki), fatwa sahabat, tabi' in dan tabi'ut tabi' in yang diperoleh berdasarkan hasil ijtihad. ${ }^{17}$

Sebenarnya antara syariah dan fikih mempunyai hubungan yang erat, sebab fikih adalah formula yang dipahami dari syariah. Demikian pula syariah tidak bisa dijalankan dengan baik, tanpa dipahami melalui fikih atau pemahaman yang memadai dan diformulasikan secara baku. Fikih sebagai hasil usaha mamahami, sangat dipengaruhi oleh tuntutan ruang dan waktu yang melibatkan Fukaha yang memformulasikannya. Karena itulah, sangat wajar jika kemudian ada perbedaan dalam rumusan mereka: ada fikih Syafi'i, Maliki, Hanafi dan Hambali, bukan syariah Syaf'i, Maliki, Hanafi, Hambali atau pun mazhab yang lain. ${ }^{18}$

Sebagaimana diketahui, syariah sebagai hukum yang ditetapkan Allah, baik yang terekam dalam Alquran maupun hadis sebagian besar bersifat global dan berbentuk pedoman. Dalam pengertian seperti ini, syariah adalah hukum in abstracto, sedangkan fikih merupakan hukum terapan hasil pemahaman yang mendalam dari sumbernya, dan dikatakan sebagai hukum in concreto. ${ }^{19}$

Perbedaan antara syariah dan fikih dapat diformulasikan secara rinci sebagai berikut:

1. Syariah mempunyai ruang lingkup yang luas, meliputi segala aspek kehidupan manusia; sementara fikih hanya menyangkut halhal yang pada umumnya dipahami sebagai aturan-aturan hukum semata.

2. Syariah ditetapkan oleh Allah dengan wahyu, sedangkan fikih ditetapkan oleh manusia (mujtahid) melalui ijtihad.

3. Syariah bersifat sempurna dan tidak berubah,

\footnotetext{
16 'Abd. Wahhab, 'Ilm Ushul al-Figh..., h. 11

${ }^{17}$ Hasbi As Shiddiqi, Pengantar Ilmu Perbandingan Mazhab (Jakarta: Bulan Bintang, 1975), h. 23

${ }^{18}$ Ahmad Rafiq, Hukum Islam di Indonesia..., h. 5

${ }^{19}$ Ahmad Rafiq, Hukum Islam di Indonesia..., h. 237
} 
sedangkan fikih terus berkembang dan berubah sesuai dengan perbedaan tempat, waktu, dan orang yang memahaminya.

4. Syariah bersifat umum dan universal, sedangkan fikih bersifat lokal.

5. Ketentuan syariah menjadi kaharusan bagi manusia untuk malaksanakan atau meninggalkan tanpa mengenal batas ruang dan waktu. Setiap orang yang memenuhi syarat untuk melaksanakan suatu perintah, maka harus melakukannya. Sedangkan fikih yang dipahamai seseorang tidak menjadi keharusan bagi orang lain untuk mengikutinya.

6. Syariah mempunyai kebenaran yang mutlak, sementara fikih karena dihasilkan dari produk ijtihad, maka terdapat kemungkinan terjadi kesalahan. ${ }^{20}$

Dari sini dapat diberikan suatu kesimpulan bahwa syariah Islam adalah satu dan tidak berubah-ubah. Hukum-hukum Allah dan teksteks Alquran adalah tetap, tidak berubah dan tidak berganti. Ia tidak pernah surut dari masa ke masa dan dari masyarakat ke masyarakat lainnya. Oleh sebab itu, perubahan dan pergantian hanyalah mengenai upaya penyesuaian dan penerapan hukum-hukum Allah tersebut dengan kondisi masyarakat dan situasi zaman. Dengan kata lain, fikih pada hakekatnya merupakan hasil usaha penyelarasan syariat dengan kondisi mayarakat dan zamannya. Khusus konteks Indonesia, fikih juga harus disesuaikan dengan kondisi sosiokultural bangsa Indonesia yang dikenal dengan istilah "Fikih Indonesia atau Fikih Nusantara" sebagaimana akan dijelaskan pada pembahasan berikutnya.

\section{Hermeneutik dan Implikasinya Terhadap Syariah}

Teori ilmu pengetahuan berputar pada subjek ke objek, objek ke subjek, dan kembali pada

${ }^{20}$ Perbedaan Syari'ah dan Fiqh tersebut adalah pendapat Umar Sulaiman dalam kitab Tarikh al-Figh al-Islamiy yang dikutip oleh Mun'im A. Sirry, pada buku yang sama pada halaman. 17-18. Bandingkan dengan S. Waqar Ahmad Husaini, Sistem Pembinaan Masyarakat Islam (Bandung: Pustaka Salman ITB, 1983/1403), h. 76-79. subjek-objek. $^{21}$ Hermeneutik yang dibangun oleh Otto Apel misalnya, secara metodologis merenovasi kembali peranan subjek sebagai sang penafsir atas objeknya. Dimana penafsiran terhadap sesuatu objek misalnya, dihasilkan melalui proses komunikasi intersubyektif sebagai suatu syarat dasar bagi pemahaman yang oleh Apel disebut dengan hermeneutik kritis. ${ }^{22}$ Dalam dunia antropologis pengetahuan, Otto Apel memberikan "prinsip regulatif", yaitu prinsip pemikiran yang selalu berupaya perbaikan dan penyempurnaan seiring dengan perubahan ruang dan waktu. Prinsip ini akan memberikan ruang emansipatoris membentuk masyarakat yang bebas dengan memperkenalkan konsep komunikatif.

Hermeneutik kritis membentuk kondisi progress possibility bagi kehidupan beragama manusia. Hermeneutik kritis merupakan upaya kombinasi epistimologi Amerika dengan epistimologi Jerman, yaitu epistimologi miliorisme oleh pemikiran

21 Pada abad pertengagan yang laris dibicarakan dengan penekanan obyek. Antitesis kemudian muncul rasionalisme modern dengan aksentuasi kutub subyek. Kemudian muncul teori.

${ }^{22}$ Teori kritis merupakan ideologi eksritik (Kritik Ideologi), yaitu suatu refleksi-diri untuk membebaskan pengetahuan manusia bila pengetahuan itu terjerumus dan membeku baik transendental maupun empiris. Teori kritis sebagai suatu metodologi yang berisi di dalam ketegangan dialektis antara filsafat dan ilmu social. Bagi Apel menggunakan istilah kritik ideologi dan kritik ilmu pengetahuan. Apel mengkritik epistimologi neopositivistik dengan menggunakan term "erklären" (ekplanasi) dan "verstehen"(pemahaman). Erklären merupakan dasar pemahaman bagi ilmu-ilmu alam, sedangkan verstehen menjadi dasar bagi ilmu-ilmu budaya (humaniora). Apel membedakan istilah kedua di atas dengan pendekatan kritik ideologi.

Aple mendukung kritik ilmu pengetahuan, berdasarkan pandangan Habermas tentang teori kepentingan-kepentingan kognitif. Menurut Apel bahwa kritik ilmu pengetahuan merupakan sumbangan pertatutan teori dan praksis dalam masyarakat. Menurut Apel menganggap teori itu telah berhasil menunjukan kesalah pahaman dari positivisme logis yang merasa yakin dapat mempersatuakan ilmu-ilmu di bawah satu metodologi, yaitu metodologi empiris-analitis ilmu-ilmu tentang alam. Aspek praksis pemikiran Apel adalah sebagai berikut: 1) Mediation of Various traditions. 2) Co-understanding, 3) Consensus 4) One Common joint history. Lihat Lihat F. Budi Hardiman, Kritik Idiologi: Menyingkap Kepentingan Pengetahuan Bersama Jürgen Habermas (Yogyakarta: Buku Baik, 2004), H. 324-325. Lihat juga Moh. Dahlan, "Pemikiran Hermeneutik Karl Otto Apel: Dari Teoritis Menuju Praktis", dalam Nafisul Atho'-Arif Fahrudin, Hermeneutik Transendental: Dari Konfigurasi Filosofis menuju Prakziz Islamic studies (Yogyakarta: IRCiSoD, 2003), h. 183. Lihat juga Lihat juga Franz Magis-Suseno, Filsafat sebagai Ilmu Kritis (Yogyakarta: Kanisisu, 1992), h. 46-48. 
James. ${ }^{23}$ Dimana asumsi manusia berada dalam tak keberdayaannya, sehingga berusaha membangun pragmatisme lewat studi yang berkenaan dengan psikologi dan kebutuhan vital manusia. Dalam hal ini, filsafat pragmatisme lebih mementingkan aspek manfaat ke depan, akibat-akibat, dan hasil praksis filsafat. Kemudian epistimologi from life menempatkan bahasa pada tempat yang sesuai dengan konteksnya.

Namun demikian, kalau ditarik ke wilayah fikih dewasa ini, tidak bisa dipungkiri bahwa meminjam istilah Gidden, dunia ini dan saat ini berjalan sebagaimana mahluk Juggernaut (truk besar), sebuah dunia yang berjalan tanpa kendali (the runway world), menerjang apa saja di depannya. Orang hanya bisa pasrah dan berdoa, memohon keselamatan agar tidak ikut diterjang. Efek dari paradigma otoritatif yang subjektif melahirkan interpretatif stereotipe. Satu pihak masih adanya truth claim, itu dapat dilihat misalnya seperti kejadian pengkafiran, fatwa hukuman mati terhadap Ulil Abshar Abdalla, dalam tulisannya di harian Kompas. ${ }^{24}$ Demikian pula Nashr Hamid Abu Zayd, dengan dua bukunya, Al-Imam al-Syafi'i dan Naqd AlKhithab al-Dini, ${ }^{25}$ kasus Taslima Nasrin berkat novelnya berjudul Lajja, ${ }^{26}$ dan masih banyak

\footnotetext{
${ }^{23}$ James mengkritik pragmatik Peirce, dengan mengarahkan tidak menyukai pragmatik Peirce. Ia menyamaratakan doktrin Peirce untuk meliputi semua konsep, kepercayaan, dan tindakan; ia juga menerapkan seorang yang pragmatis gagasan ke kebenaran seperti halnya ke maksud/arti. James, tertarik akan terungkap bagaimana sistem kesusilaan, agama, dan iman bisa dipertahankan di dalam suatu peradaban ilmiah. Ia berargumentasi bahwa perasaan, seperti halnya logika, adalah rumit ke rasionalitas dan isu-isu kehidupan-moral yang agung dan kepercayaan religius, contoh lompatan-lompatan iman. Sedemikian, mereka tergantung pada apa yang ia sebut "kehendak untuk percaya" dan tidak melulu pada bukti ilmiah, yang mana tidak pernah dapat menceritakan kami, harus berbuat apa atau apa yang bermanfaat. James Kritikus membebankan dengan relativism (kepercayaan yang menilai tergantung pada situasi spesifik) dan dengan kelayakan sangat bodoh untuk pengusulan bahwa jika suatu tindakan atau gagasan berhasil/bekerja halal orang berniat, harus benar. Tetapi James dapat dengan teliti diuraikan sebagai seorang pluralis yang percaya dunia yang kompleks untuk tiap orang filosofi untuk menjelaskan segalanya.

${ }^{24}$ Ulil Abshar-Abdalla, "Menyegarkan Kembali Pemahaman Islam”, Kompas, 18 November 2002.

${ }^{25}$ Moch. Nur Ichwan, Meretas Kesarjanaan Al-Quran: Teori Hermeneutika Nasr Abu Zayd (Bandung: Teraju, 2003), h. 22-26.

${ }^{26}$ Novel ini berkisah tentang "13 hari kehidupan keluarga
}

lagi kejadian-kejadian serupa. Inilah problem internal umat Islam yang sangat konservatif dengan hal-hal baru di dalam wacana Islam.

Kejadian semacam itu, pada dasarnya disebabkan oleh sikap yang tekstualis-paradigmatis terhadap kitab suci, ${ }^{27}$ tafsir terhadap fikih klasik yang apa adanya, sehingga "takut" mengikuti perubahan-perubahan zaman seiring dengan kemajuan ilmu pengetahuan dan teknologi, yang selalu melahirkan "kerumitan-kerumitan baru”. Ziauddin Zardar dalam bukunya, Islam, Postmodernism and Other Future, menyatakan bahwa tafsir semacam itu adalah "penjelasan orang-orang yang malas untuk berpikir secara otokritik". ${ }^{28}$

Langkah awal yang mesti diperbuat adalah "berani untuk melakukan penelaahan yang kritis dan rasional atas segenap warisan-warisan otoritatif masa silam, termasuk fikih lokal di mana umat hidup. ${ }^{29}$ Dengan demikian, umat Islam mestinya harus mulai "berani untuk berhenti mencari legitimasi otoritas agama maupun "teks-teks yang dianggap suci" untuk membangun konfigurasi intelektual". ${ }^{30}$ Jadi, yang perlu dilakukan, seperti ungkatan Thomas Khun, 'pergeseran paradigma' (shifting paradigm) dari otoritatif-dogmatis, ke arah paradigma komunikatif-dialektik, antara gagasan dipertautkan dan diolah untuk menggagas nilai-nilai universal untuk dapat "diobjektifkan", dan proses itu diandaikan akan terus berlanjut dalam suasana "bebas dari paksaan".

Sebagai contoh, dahulu trend kontroversi istilah bayi tabung (kloning) karena proses pembuatannya tidak dalam rahim manusia. Di mana seorang perempuan sebagai dokter

Hindu yang diteror dan dikecam ketakutan oleh kaum fundamentalis di Banglades yang ingin membalas pembakaran Masjid Babri di Ayodhya, India, oleh fundametalisme Hindu". Lihat Umi Kulsum, "Ketika Agama Menjadi Topeng Kekerasan" dan "Taslima Nasrin: Perjuang Anti-Komunalisme", Kompas, 19 Juni 2004, h. 58.

27 Ulil Abshar-Abdalla, "Menghindari Bibliolatri: Tentang Pentingnya Menyegarkan Kembali Pemahaman Islam", Teks Ceramah di Paramadina, 8 Februari 2003.

28 Pernyataan itu dikutip dari Airlangga Pribadi dalam "Melampaui Nalar Sakralisasi Agama”, Jawa Pos, 27 Juni 2004, h. 4.

${ }^{29}$ Airlangga Pribadi, "Melampaui Nalar...", h. 4

${ }^{30}$ Airlangga Pribadi, "Melampaui Nalar...”, h. 4. 
mempunyai anak yang divonis gagal kehamilan, yang mengancam kehidupan anaknya, kemudian ibunya sebagai dokter membuat keputusan bahwa ovum dan sperma dimasukkan ke dalam rahimnya sampai bayi itu lahir. Kasus ini yang menjadi sebuah tantangan umat Islam untuk membentuk masyarakat yang maju sesuai perkembangan teknologi.

Begitu juga memahami keberagamaan (fikih termasuk di dalamnya) meminjam istilah M. Amin Abdullah harus ditempatkan secara seimbang antara pendekatan normatif dan historis. Maka dibutuhkan kreativitas dan inovasi secara konsisten. Kritik atau dialog dalam studi agama merupakan jalan lain untuk menemukan pemahaman yang kompleks baik individu maupun kelompok terhadap tradisi teks keagamaan. Hal ini membentuk masyarakat yang komunikatif yang mengedepankan etikadialogis sebagai dasar paksis dalam membaca intersubjektif keberagamaan manusia. ${ }^{31}$

Dengan demikian, prosess posibiliy dalam tradisi hermenuetika kritis perlu terus dihadapkan dengan syariah untuk menghasilkan fikih dengan paradigma baru. Kalau hanya menyerah dan menerima apa adanya, maka nilai-nilai universal syariah bisa tergusur dan terciutkan oleh angin globalisasi dan teknologi yang tidak mengenal ampun, seperti perumpamaan Gidden di atas. Nilai-nilai fikih lokal dengan demikian diharuskan tumbuh di setiap negara, tak terkecuali Indonesia yang mayoritas beragama Islam.

\section{Reorientasi Fikih Indonesia}

Agaknya sudah menjadi kesepakatan di kalangan pemikir kontemporer bahwa perubahan sosial tidak hanya mengubah fikih dalam pengertian furu' (cabang cari syariah), tetapi juga menimpa pada tataran usul (inti agama). Seiring perubahan sosial demikian besarnya yang mempengaruhi konsep dan lembaga hukum sehingga dibutuhkan filsfat hukum sekaligus antropologi hukum. ${ }^{32}$

31 M. Amin Abdullah, Studi Agama: Normativitas atau Historisitas?, (Yogyakarta: Pustaka Pelajar, 1996), h. vi-vii.

32 Muhammad Khalid Masud, Islamic Legal Philosophy:
Sebagaimana telah disinggung dalam pendahuluan, sebenarnya ide tentang "Fikih Nasional/ Fikih Indonesia" dimunculkan oleh Prof. Hazairin (guru besar hukum Islam dan hukum adat Universitas Indonesia) dan Prof. Hasbi As Shiddiqi (guru besar Ilmu Syariah) IAIN Sunan Kalijaga Yogyakarta yang sekarang berubah menjadi UIN. Meskipun konsep yang diajukan dua guru besar itu tampil sendiri-sendiri, tetapi tidak terlepas dari kerangka pembaruan yang selalu didengungkan dan diinginkan di Indonesia.

Pada tahun lima puluhan, Hazairin menggulirkan idenya tentang fikih mazhab nasional dalam lapangan yang langsung mempunyai kepentingan kemasyarakatan. Secara garis besar, inti dari gagasan beliau adalah sebagai berikut:

1. Perlunya memberikan corak kenasionalan bagi perkembangan hukum Islam di Indonesia, dengan merangkumnya dalam suatu mazhab nasional guna menonjolkan hal-hal yang sifatnya spesifik.

2. Dalam rangka memberikan identitas Nasional terhadap hukum Islam Indonesia, diadakan pembedaan dalam dua bidang:

- Hukum Islam yang berkaitan dengan ibadah;

- Hukum Islam yang berkaitan dengan kemasyarakatan

3. Mazhab Syafi'i tetap dipertahankan dalam bidang ibadah, sedangkan bidang kemasyarakatan didirikan mazhab Nasional.

4. Untuk membentuk mazhab Nasional diperlukan lahirnya mujtahid-mujtahid baru yang bercorak nasional untuk melakukan ijtihad/penerapan hukum Islam yang sesuai dengan situasi dan kondisi di Indonesia. ${ }^{33}$

Gagasan tersebut dipertajam lagi oleh Hasbi sekitar tahun enam puluhan. Beliau menyatakan perlunya membina fikih yang berkepribadian

A Stud Of Abu Ishaq Al-Shatib's Life And Thouth, (Delhi: Internasional Islamic Publishers, 1989), h. 1.

${ }^{3}$ Syamsul Wahidin dan Abdurrahman, Perkembangan Ringkas Hukum Islam di Indonesia, (Jakarta: Akademika Pressindo, 1984), h. 87-88. Lihat pula Hazairin, Hendak Kemana Hukum Islam, (Jakarta: Tintamas, 1976), h. 3-6, Pengarang yang sama, Hukum Keluarga Nasional, (Jakarta: Tintamas, 1982), h. 5-6. 
atau fikih yang berwawasan keindonesiaan, fikih yang cocok dengan keadaan dan kebutuhan mayarakat Indonesia, fikih yang mampu memecahkan persoalan-persoalan hukum yang timbul di kalangan mayarakat Indonesia. Hal ini mengingat pada waktu itu fikih kurang mendapat sambutan yang hangat dari umat Islam Indonesia. Salah satu sebabnya adalah adanya bagian-bagian fikih yang berdasarkan Urf di Timur Tengah yang tidak sesuai dengan rasa kesadaran hukum masyarakat Indonesia yang telah melembaga dalam hukum adat. Bagianbagian fikih seperti ini tentunya terasa asing bagi mereka, akan tetapi dipaksakan untuk dilaksanakan dengan dasar taqlid.

Agar fikih mendapat dukungan yang hangat dari masyarakat di kalangan bangsa Indonesia, maka dalam mengkaji fikih para ulama Indonesia harus mencari pendapat yang lebih sesuai dengan watak dan tabiat bangsa Indonesia serta cocok dengan alam pikiran masa kini.

Salah satu hal yang perlu dikembangkan untuk dapat membentuk fikih Indonesia adalah Urf. Menurut Hasbi, Urf yang menjadi salah satu sumber hukum ialah adat kebiasan yang dipandang baik oleh akal sehat dan dapat diterima oleh tabiat manusia. ${ }^{34}$ Karena itu, para fukaha dahulu pun dalam mengeluarkan fatwa hukum, dalam banyak hal berdasarkan 'urf di lingkungan masyarakatnya. Selanjutnya, dalam menggunakan 'urf sebagai sumber hukum, timbul permasalahan, 'urf mana yang dijadikan sebagai norma dan patokan. Apakah 'urf Arab, Mesir, Irak, India yang telah ditransfer ulama-ulama dahulu ke dalam kitab-kitab fikih yang mereka susun? padahal pepatah Indonesia mengatakan:" Lain Lubuk lain Ikannya, lain Ladang lain Belalang" dan pepatah Jawa: "Seje Deso mowo coro". Maksudnya tidaklah sama 'urf dari setiap bangsa.

${ }^{34}$ Hasbi As Shiddiqi, Pokok-pokok Ilmu Dirayah Hadis, (Jakarta: Bulan Bintang, 1981), h. 34. Menurut Azhar Basyir, 'Urf itu ada dua macam. "Urf Shahih dan urf Fasid. Dalam hal ini, yang pertamalah yang dapat dijadikan sebagai dasar penentuan hukum, yakni 'urf/adat istiadat yang dapat diterima oleh masyarakat luas, dibenarkan oleh akal sehat, membawa kemaslahatan serta tidak menyalahi ketentuan nash al-Qur'an dan Sunnah Rasul. Lihat Ahmad Azhar Basyir, 'Pokok-pokok Ijtihad Dalam Hukum Islam” dalam Jalaludin Rahmat (ed), Ijtihad Dalam Sorotan (Bandung, Mizan, 1992), h. 52.
Masing-masing bangsa mempunyai 'urf sendirisendiri yang merupakan bagian dari struktur kebudayaan yang mereka miliki. Sedangkan suatu kebudayaan dibentuk oleh lingkungan dan sekelilingnya. Karena itu, karakter kebudayaan Timur Tengah yang ditempa lingkungan alam yang gersang dan panas, tentu tidak sama karakter kebudayaan yang ditempa lingkungan alam yang subur dan teduh. Bagi orang Indonesia, memakai pakaian yang ringkas tidak sampai menimbulkan masalah bagi kesehatan, namun bagi bangsa Arab akan berakibat fatal. Zat cair dalam tubuh mereka bisa cepat mengering lantaran tingkat penguapan yang tinggi. Oleh sebab itu, sesuatu yang harus bagi masyarakat Arab belum tentu harus pula bagi masyarakat Indonesia, demikian pula sebaliknya. Adalah suatu kesalahan besar jika adat istiadat Makkah dipaksakan diterapkan di Indonesia. ${ }^{35}$

Sebagai contoh yang paling jelas tentang adanya pengaruh 'urf dalam menentukan hukum ialah berbedanya fatwa imam Syafi'i ketika dia berdomisili di Iraq yang disebut qaul qadim (pendapat lama) dengan fatwa ketika dia di Mesir yang disebut dengan qaul jadid (pendapat baru). Contoh lain adalah sistem hukum yang dianut masyarakat Hijaz (Maliki) berciri tradisionalis, sedangkan di Iraq (Abu Hanifah) bercirikan rasionalis seperti yang dipegang oleh Umar bin Khattab dan kemudian dikembangkan oleh Abdullah bin Mas'ud di Iraq. ${ }^{36}$

Secara ringkas, pikiran Hasbi tentang Fikih Indonesia dapat dijelaskan sebagai berikut:

1. Fikih Islam yang berkepribadian Indonesia adalah hal yang mungkin bahkan patut dibina.

2. 'Urf masyarakat Indonesia dapat dijadikan sebagai sumber fikih yang diterapkan di Indonesia.

3. Terhadap masalah-masalah baru yang belum ada ketetapan hukumnya, juga tidak ada dalam 'urf, supaya dilakukan ijtihad dengan menggunakan, metode analogi deduksi rasional dengan pendekatan kontekstual

\footnotetext{
${ }^{35}$ Nourouzzaman Shiddiqi, Jeram-jeram Peradaban Muslim, (Yogyakarta: Pustaka Pelajar, 1990), h h. 240.

${ }^{36}$ Nourouzzaman Shiddiqi, Jeram-jeram..., h. 241
} 
(sosio kulturals historis) pada dalil-dalil nash.

4. Ijtihad supaya dilakukan secara kolektif (jama'i) dengan melibatkan pakar agama dan seluruh cabang ilmu pengetahuan.

5. Teori dan kaidah produk pemikiran fukaha terdahulu tetap relevan dan supaya dijadikan sebagai acuan dalam pemikiran pembaharuan hukum Islam.

6. Terhadap masalah-masalah hukum yang telah ada ketetapan hukumnya produk ijtihad fukaha terdahulu, dalam memilih salah satu di antaranya mana yang terbaik dan paling cocok dengan situasi dan kondisi masyarakat Indonesia, supaya dilakukan kajian komparasi terhadap seluruh mazhab yang telah ada.

7. Pembaruan hukum yang meninggalkan atau bertentangan dengan Alquran dan sunah, tidak dapat dibenarkan. ${ }^{37}$

Pada hakekatnya, gagasan dari kedua tokoh tersebut di atas, mempunyai titik tujuan yang sama, yaitu terbentuknya fikih yang berkepribadian Indonesia, fikih yang cocok dengan keadaan dan kebutuhan masyarakat Indonesia dan fikih yang mampu menjawab persoalan-persoalan hukum yang timbul di kalangan masyarakat Indonesia. Kedua tokoh tersebut berjasa sebagai penggagas pertama tentang fikih Indonesia dan mempunyai andil besar dalam catatan sejarah pembaharuan fikih di Indonesia. Sebagai bukti dari manifestasi fikih Indonesia antara lain:

a) Undang-undang Nomor I tahun 1974 tentang perkawinan;

b) Undang-undang Nomor 7 tahun 1989 tentang Peradilan Agama;

c) Instruksi Presiden Nomor I tahun 1991 tentang Kompilasi Hukum Islam di Indonesia.

Pada masa-masa berikutnya, muncul tokohtokoh baru yang mempunyai gagasan serupa sekalipun kita tidak dapat mengatkaan secara pasti bahwa gagasan mereka itu dipengaruhi oleh dua tokoh di atas. Di antara mereka adalah Abdurrahman Wahid (Pribumisasi Islam, 1988),

\footnotetext{
${ }^{37}$ Nourouzzaman Shiddiqi, Jeram-jeram..., h. 250
}

Munawir Syadzali (Reaktualisasi Ajaran Islam, 1988); Masdar Farid Mas `udi (Zakat sebagai Pajak, 1991); Syeikhul Hadi Permono (Kontekstualisasi Fikih Dalam Era Globnalisasi, 1994); Ali Yafie (Menggagas Fikih Sosial, 1994) $^{38}$.

Gagasan tentang fikih Indonesia yang dimunculkan oleh tokoh-tokoh sebagaimana dijelaskan sebelumnya, nampaknya dapat memberikan fenomena baru bagi perkembangan hukum Islam di Indonesia dengan hasil-hasil konkrit yang dapat kita rasakan manfaatnya. Rumusan tentang fikih Indonesia menurut penggagasnya, sebenarnya sudah menampilkan suatu rumusan yang operasional dan mendekati sempurna, namun demikian gagasan tersebut perlu adanya dukungan dan langkah-langkah ke arah konsep yang lebih sempurna seiring dengan kemajuan zaman dan dinamika masyarakat.

Tanpa melupakan penghargaan kita kepada kitab-kitab fikih yang telah mengantarkan kita untuk dapat memahami hukum Islam, kita juga melihat keterbatasan-keterbatasannya. Formulasi hukum yang ada di sana sudah berusia relatif agak lama. Sedangkan pergeseran kemaslahatan akibat perkembangan kebudayaan sangat cepat. Di sinilah dituntut keberadaan Ijtihad untuk dapat menjawab persoalan yang muncul dan belum dijelaskan pada kitab-kitab fikih terdahulu. Kita meyakini bahwa sampai saat ini pintu ijtihad masih terbuka. Ijtihad dilakukan dengan "bebas bertanggung jawab". Bebas dalam arti ijtihad tidak dilarang, dan bertanggung jawab dalam arti diperbolehkan atau diwajibkannya ijtihad itu hanya bagi mereka yang memenuhi prakualifikasi, dengan bermaksud untuk mencari kemaslahatan umat secara umum. ${ }^{39}$

Orang-orang yang telah memenuhi prakualifikasi berijtihad dapat disebut sebagai

38 Semula Ali Yafie mengkritik dan bahkan tegas-tegas menolak kehadiran fiqh Indonesia. Lihat Yudian W. Asmin dalam Sudarnoto Abd Hakim dkk (ed), Islam Berbagai Perspekti, (Yogyakarta: LPMI, 1995), h. 223. namun belakang beliau cenderung mendukungnya. Hal ii terlihat dalam tulisan-tulisan a.l. "Pengembangan Ilmu Fiqh", Fiqh Dalam Pembaharuan Islam di Indonesia" Lihat Ali Yafie, Menggagas Fiqh Sosial, (Bandung: Mizan, 1994), h. 107-122.

39 Syeikhul Hadi Permono, Kontekstual Figh Dalam Era Globalisasi, (Surabaya, 1994), h. 28 
Mujtahid atau Faqih yang mampu beristinbat (mengeluarkan) hukum dari dalil-dalilnya secara metodologis sesuai dengan rambu-rambu metodologis fikih (Usul Fikih). Orang-orang seperti itulah yang seharusnya kita produksi dalam jumlah yang besar pada saat sekarang ini, bukan hanya orang-orang yang mampu membaca kitab-kitab kuning, faham tentang produk-produk fikih namun tidak mengerti metodologi fikih. Dengan kata lain, harus mengaktualkan ijtihad sesuai dengan fungsinya, mencetak kader-kader mujtahid, fukaha, ulama dan para peneliti dengan spesialisasi khusus yang betul-betul mengerti metodologi fikih. Dari sini proses ijtihad dalam menentukan hukum bisa berjalan secara prosedural. Penggunaan Qiyas, Istihsan, Maslahah Mursalah, 'Urf dan sebagainya tidak menyimpang dari rambu-rambu yang telah digariskan oleh Islam. Yang menjadi permasalahan berikutnya adalah bagaimana upaya untuk mewujudkan gagasan tentang aktualisasi ijtihad dan menciptakan kader-kader mujtahid, ulama dan peneliti yang betul-betul paham metodologi fikih sebagaimana yang ditawarkan di atas?

Selama ini kajian tentang metodologi fikih sebenarnya sudah diberikan dalam berbagai tingkatan misalnya di madrasah-madrasah, pesantren, perguruan-perguruan tinggi agama, khususnya di fakultas Syari'ah namun dirasa masih kurang dan perlu ditingkatkan lagi dengan menambah jam-jam pelajaran, bobot sksnya dan penyempurnaan metodologi pengajaran. Bahkan kalau perlu, didirikan fakultas Usul Fikih atau paling tidak jurusan Usul Fikih, yang pada konteks sekarang ini barangkali lebih tepat dilaksanakan di tingkat Pascasarjana di lingkungan UIN, yang selama ini hanya memberikan bobot 3 sks dalam mata kuliah Metodologi Fikih.

\section{Penutup}

Setiap orang muslim meyakini ajaran terakhir yang diwahyukan Allah Swt. kepada RasulNya, tidak ada rasul yang diutus dan wahyu yang diturunkan sesudahnya. Hal ini memberikan pengertian bahwa Islam yang dinyatakan sempurna pada akhir hayat Rasulullah itu benar-benar membawa ajaran yang memiliki dinamika yang sangat tinggi dan sifat luwes yang dapat menjamin kemampuannya untuk menampung segala macam persoalan dan permaslahan yang timbul akibat perkembangan masyarakat dan kemajuan zaman dalam segala bidang dan menjamin relevansinya sepanjang masa dalam berbagai kondisi dan lingkungan sosial. Ini membawa konsekuensi hukum Islam seharusnya sanggup menghadapi, memberikan jawaban dan antisipasinya terhadap semua per-kembangan dan kejadian-kejadian baru, kapan dan dimana saja, sehingga tetap aktual. Karena itu, sangat diperlukan upaya-upaya konkrit untuk direalisasikan obsesi tersebut. Kalau tidak, maka hal itu dapat membuat hukum Islam (fikih lokal) akan ditinggalkan karena dianggap kurang bisa menyajikan kekayaan yang dimiliki Islam sebagai agama terakhir yang sempurna, pada gilirannya, kharismanya sebagai agama akan luntur dan dianggap sebagai barang antik yang hanya layak untuk dipajang dalam mesium. ${ }^{40}$ Oleh sebab itu, diperlukan keberanian untuk selalu mengorientasikan prosses posibiliy syariah dimana para pemikir dan intelektual agama tersebut hidup. Contoh gagasan fikih Nasional/ Indonesia tentu fikih yang berkepribadian dan berwawasan keindonesiaan, yang cocok dengan keadaan dan kebutuhan masyarakat Indonesia seperti dimunculkan oleh Hazairin dan Hasbi AsShiddiqi perlu disambut dengan baik. Fikih dalam tawaran ini, paling tidak mampu memecahkan persoalan-persoalan hukum yang timbul di kalangan masyarakat Indonesia seiring dengan dinamika sosial dan kemajuan zaman. Maka, harus disosialisasikan reorientasi gagasan di atas dengan mengaktualkan gerakan ijtihad, mencetak kader-kader mujtahid dan fukaha yang betul-betul menguasai teori, metodologi Usul Fikih, materi, dan memahami kondisi sosial masyarakat.

\section{Pustaka Acuan}

Abdalla, Ulil Abshar, "Menghindari Bibliolatri: Tentang Pentingnya Menyegarkan Kembali Pemahaman Islam", Teks Ceramah di Paramadina, 8 Februari 2003.

Abdalla, Ulil Abshar, "Menyegarkan Kembali

\footnotetext{
${ }^{40}$ Nourouzzaman Shiddiqi, Jeram-jeram..., h. 234
} 
Pemahaman Islam", Kompas, 18 November 2002.

Abdullah, M. Amin, Studi Agama: Normativitas atan Historisitas?, Yogyakarta: Pustaka Pelajar 1996.

Ali, Mohammad Daud, Hukum Islam, Pengantar Ilmu Hukum dan Tata Hukum Islam di Indonesia, Jakarta: Raja Grafindo Persada, 1993.

Ash-Shiddiqi, Hasbi, Pokok-pokok Ilmu Dirayah Hadis, Jilid I, Jakarta: Bulan Bintang, 1981.

Ash-Shiddiqi, Hasbi, Syariat Islam Menjawab Tantangan Zaman, Jakarta: Bulan Bintang, 1966.

Asmin, Yudian W. dalam Sudarnoto Abd Hakim dkk (ed), Islam Berbagai Perspektif, Yogyakarta: LPMI, 1995.

Asyur, Muhammad Thahir bin, Maqashid alSyariah al-Islamiyyah, Malaysia: Dar al-Fajr, 1999.

Badran, Abu al-"Ayn Badran, Ushul al-Figh alIslamiy, Iskandariyah: Muassasah al-Saqafat alJami' iyyah, t.th.

Basyir, Azhar, 'Pokok-pokok Ijtihad Dalam Hukum Islam" dalam Jalaluddin Rakhmat (ed), Ijtihad Dalam Sorotan, Bandung: Mizan, 1992.

Dahlan, Moh., "Pemikiran Hermeneutik Karl Otto Apel: Dari Teoritis Menuju Praktis", dalam Nafisul Atho'-Arif Fahrudin, Hermeneutik Transendental: Dari Konfigurasi Filosofis menuju Prakziz Islamic Studies, Yogyakarta: IRCiSoD, 2003.

Hardiman, F. Budi, Kritik Idiologi: Menyingkap Kepentingan Pengetahuan Bersama Jürgen Habermas, Yogyakarta: Buku Baik, 2004.

Hasan, Ahmad, Pintu Ijtihad Sebelum Tertutup, Terj. Agah Garnadi, Bandung: Pustaka, 1994.

Hazairin, Hendak Kemana Hukum Islam, Jakarta: Tintamas, 1976.

Hazairin, Hukum Keluarga Nasional, Jakarta: Tintamas, 1982.

Hazairin, Tujuh Serangkai tentang Hukum, Jakart: Tintamas, 1974.

Hosen, Ibrahim, "Pemerintah sebagai Mazhab", Jurnal Pesantren, No. 2 Vol. II 1985.
Husaini, Waqar Ahmad, Sistem Pembinaan Masyarakat Islam, Bandung: Pustaka Salman ITB, 1983/1403.

Ichwan, Moch. Nur, Meretas Kesarjanaan AlQuran: Teori Hermeneutika Nasr Abu Zayd Bandung: Teraju, 2003.

Khallaf, Abd. Wahhab, 'Ilm Ushulal-Fikih, Kuwait: Dar al-Qalam, 1978/1398.

Khin, Musthafa Said al-, al-Kafi al-Wafi fi Ushul al-Figh al-Islamy, Beirut: Muassasah al-Risalah, 2000.

Kulsum, Umi, "Ketika Agama Menjadi Topeng Kekerasan" dan "Taslima Nasrin: Perjuang Anti-Komunalisme”, Kompas, 19 Juni 2004.

Nourouzzaman Shiddiqi, Jeram-jeram Peradaban Muslim, (Yogyakarta: Pustaka Pelajar, 1990).

Nyazee, Imran Ahsan Khari, Theories of Islamic Law: The Methodology of litihad Islamabad: The Intemational Institute of lslamic Thought, 1994.

Permono, Syeikhul Hadi, Kontekstual Figh Dalam Era Globalisasi, Surabaya, 1994.

Qardlawi, Yusuf, "Awamil al-Sa'ah Wa al-Murunah Fi al-Syariat al-Islamiyyah", Terjemahaan S. Agil Husein Al-Munawwar dengan judul Keluasan dan Keluwesan Hukum Islam, Semarang: Dina Utama Semarang/Toha Putra Group, 1993.

Rafiq, Ahmad, Hukum Islam di Indonesia, Jakarta: Raja Grafindo Persada, 1995.

Sirry, Mun'im A., Sejarah Figh Islam sebuah Pengantar, Surabaya: Risalah Gusti, 1995/1416.

Suseno, Franz Magis, Filsafat sebagai Ilmu Kritis, Yogyakarta: Kanisius, 1992.

Syaltut, Mahmud, al-Islam Aqidah wa Syariah, Mesir: Dar al-Qalam, 1966.

Syathibi, Abu Ishaq al-, al-Muwafaqat Fi UshulalSyariah, Juz II,Tahqiq Abdullah Daraz, Beirut: Dar al-Kutub al-Ilmiyyah, t.th.

Turabi, Hasan al-, Qadhaya al-Tajdid: Nahwa Manhaj Ushuly, T.Tp: Dar al-Hady, 2000.

Wahidin, Syamsul dan Abdurrahman, Perkembangan Ringkas Hukum Islam di Indonesia Jakarta: Akademika Pressindo, 1984.

Yafie, Ali, Menggagas Fiqh Sosial, Bandung: Mizan, 1994. 